\title{
Approaching Ethnic Cleansing within the Criminal Law of Ethiopia
}

\author{
Addisu Genet Ayalew \\ College of Law and Governance Study, Dilla University, Dilla, Ethiopia \\ Email: addisug84@gmail.com
}

How to cite this paper: Ayalew, A. G. (2019). Approaching Ethnic Cleansing within the Criminal Law of Ethiopia. Beijing Law Review, 10, 869-881.

https://doi.org/10.4236/blr.2019.104047

Received: May 14, 2019

Accepted: August 29, 2019

Published: September 2, 2019

Copyright (c) 2019 by author(s) and Scientific Research Publishing Inc. This work is licensed under the Creative Commons Attribution International License (CC BY 4.0).

http://creativecommons.org/licenses/by/4.0/ (c) (i) Open Access

\begin{abstract}
The status of ethnic cleansing as a punishable act in the international criminal law is being a subject of quarrel. Those who reject its criminal status argue based on the principle of legality while the other group contends, lacking the existence of explicit law, still there is a room to prosecute ethnic cleansing through major international crimes like crime of genocide or crime against humanity. Although, ethnic cleansing is a crucial political and legal discourse in the current Ethiopia, it is not mentioned as a punishable act in its laws. Discovering the criminal status of ethnic cleansing under the criminal law of Ethiopia is the purpose of this paper. Basing on the accompanying crimes particularly the gravity of the offense producing ethnic cleansing and the contextual element required, this paper concludes categorizing ethnic cleansing in the crime of genocide and crime against humanity.
\end{abstract}

\section{Keywords}

Crime against Humanity, Genocide, Ethnic Cleansing, Principle of Legality, criminal Law of Ethiopia

\section{Introduction}

Defining ethnic cleansing is not a simple task. "Unlike crime of genocide and crime against humanity, ethnic cleansing is not a legal term of art" (Presbyterian Church of Sudan v. Talisman Energy, 2003). In Presbyterian Church of Sudan v. Talisman Energy Inc., the court conceives ethnic cleansing as a literal translation of the Serbo-Croatian term etnicko cis cenje, arising from atrocities in the former Yugoslavia ${ }^{1}$ (Schabas, 2001). The court understood ethnic cleansing to be "a euphemism for genocide." Yet, opinions differ as to its meaning, which has no

${ }^{1}$ The court affirms, "The view that the two terms (genocide and ethnic cleansing) are equivalent or that they overlap is, widely held within the diplomatic and academic communities." 
formal international law definition (Destroyed, 2004). The commission of experts providing that ethnic cleansing is a new terminology in the international criminal law described it as the forceful removal of an ethnic, religious or other groups from a certain location to create ethnic homogeneity in favor of the dominant group (UN commission of experts report, 1994). This definition has later incorporated by various UN resolutions, reports and tribunals including the ICTY and ICTR in addressing ethnic cleansing. ${ }^{2}$ In tandem with lack of explicit law criminalizing it, the task of determining the scope may occupy invite confusion when one thinks about its criminalization. The Commission of experts in addressing ethnic cleansing committed in the territory of the former Yugoslavia states that in the furtherance of ethnic cleansing in the Yugoslavian territory, various heinous crimes have committed associated with ethnic cleansing. In particular, "murder, torture, arbitrary arrest and detention, extra-judicial executions, rape and sexual assaults, confinement of civilian population in ghetto areas, forcible removal, displacement and deportation of civilian population, deliberate military attacks or threats of attacks on civilians and civilian areas and wanton destruction of property were committed". In doing so instead of determining the scope of the crime under the brand of ethnic cleansing it puts inspiration on the accompanying crimes in completing ethnic cleansing. Emanating from this it roughly argued that those atrocities might fall to crime of genocide, war crime or crime against humanity. Although, the tribunals established later for the respective atrocities in Rwanda and Yugoslavia tried constitutive acts of ethnic cleansing, no indictment had tried for crime of ethnic cleansing separately. In Ethiopia, though currently ethnic cleansing is widespread, ${ }^{3}$ it is having not specifically stipulated as a punishable act in the criminal code or the FDRE constitution.

${ }^{2}$ Prosecutor v. Brđjanin, Case No. IT-99-36-T, Judgment, 989 Sept. 1, 2004; Comm'n on Human Rights, Report of the Commission on Human Rights on its First Special Session, at 2, delivered to the Economic and Social Council, U.N. Doc. E/CN.4/1992/S-1/8 Aug. 14, 1992 (claiming that, at a minimum, ethnic cleansing entails "deportations and forcible mass removal or expulsion of persons from their homes" and is "aimed at the dislocation or destruction of national, ethnic, racial or religious groups"); U.N. GAOR, 47th Sess., 91st plan. mtg., at 2, U.N. Doc. A/RES/47/121, Dec. 18, 1992 (declaring that a consistent pattern of gross human rights violations, mass expulsions of defenseless civilians from their homes, and the existence of concentration camps and detention centers were carried out in pursuit of an "abhorrent policy of 'ethnic cleansing,' which is a form of genocide”); see also Prosecutor v. Al Bashir, Case No. ICC-02/05-01/09-3, Decision on the Prosecutor's Application for a Warrant of Arrest, 143 Mar. 4, 2009.

3 "Roughly" stating, For instance, according to the global report on internal displacement 2019, Ethiopia holds the top level of internally displaced persons with 2.9 million peoples. (visit https://www.thereporterethiopia.com/ accessed May 19, 2019). Furthermore the study conducted by Moresh Wogene Amhara organization research, entitling "the Amhara genocide ignored by the world"identified and exposed the suffering, genocide and ethnic cleansing of Amhara people since 1992 in Harerge, Arsi, Wollega (Bedeno), Metekel, Kemash, Bench Maji (Gura Fereda), Jimma Agaro, Afar, Bahir Dar and Gondar cities in Amhara Region. See Bekalu Atnafu, ethnic cleansing in Ethiopia, U.S. Department of State, and Country Reports on Human Rights Practices. See Muluken Tesfaw, "Perceived Causes of the Displacement of the Amharas from Benishangul-Gumuz Region and Its Effect on their Psychosocial Well-Being," MA Tesis, Faculty of Educational and Behavioral Sciences, Bahir Dar University, 2014. See also Fekade Shewakena, Ethiopia: Behind the Ethnic Cleansing in Benishangul-Gumuz, Ethiopian American News, available at http://www.ethiomedia.com/. Visited on April 12 2019. However, this researcher believes the alleged crime as stated above committed targeting against a certain ethnic group (particularly the Amhara) requires a careful and deep analysis of the atrocity in tandem with the law to arrive in a conclusion of ethnic cleansing; genocide or crime against humanity. 
This paper investigates the legal framework and justifications enabling to prosecute perpetrators of ethnic cleansing under Ethiopian criminal law. In particular, it assesses how ethnic cleansing would fall within the ambit of crime of genocide or crime against humanity. In making such conclusion, it considers the principle of legality towards the criminalization and punishment of a given crime. The paper emphasizes international law and the jurisprudence of international tribunals. There are multiple reasons to do this; firstly, due to poor jurisprudence in Ethiopian courts regarding the crime at the disposal of this paper resort to interpretation and analysis would be limited. Secondly, the FDRE constitution and the criminal code captioning crime against humanity as a (catch up clause of course) and genocide respectively, as crime against international law, invites interpretation according to international criminal law and accepted practices. Finally, crime of genocide and crime against humanity have already attained the status of peremptory norm under international law and imposes the states the obligation not to depart from these norms. Moreover, some of those norms provide universal jurisdiction so that, perpetrators will not be exonerated from prosecution even if the national state might not criminalize or criminalize these crimes in a restrictive manner.

\section{The Naming Issue under International Criminal Law}

The drafters of the Genocide Convention quite intentionally excluded a category of punishable act that would apply to our contemporary concept of 'ethnic cleansing' (Schabas, 2006). According to the drafters of the Genocide Convention the proposed addition of crime resembling to ethnic cleansing was not included in the definition ${ }^{4}$ of genocide in the convention, because U.N. members' in particular the USconcerns over already completed "forced transfers of minority groups" bythe UN itself and such inclusion may allow disruption against already placed minorities. (Ibid). However, it has noted that, in the extreme case, ethnic cleansing may constitute crime of genocide if the perpetrator has the required intention. (Ibid). Ethiopia as signatories of the Genocide Convention during its adoption on 11 December 1948 criminalizes genocide captioning it as crime in violation of international law. While no single stipulation of the word ethnic cleansing as a punishable act has mentioned.

The politics of naming crime has given a meticulous attention since it has greatest impact and is an issue among the international community considering various interests. The similarities of what has happened between Iraq and Darfur are remarkable (Mamdani, 2007). The estimate of the number of civilians killed is roughly similar. The killers are mostly paramilitaries, closely linked to the official military, which is consideredtheir main source of arms.(Ibid). The conflict between the Sudan (Khartoum) and the Darfur (black Africans) which has been waged over a decades has labeled different name by different influential in-

${ }^{4}$ See article II of the Convention on the Prevention and Punishment of the Crime of Genocide, opened for signature Dec. 9, 1948, 102 Stat. 3045, 78 U.N.T.S. 277. [hereinafter Genocide Convention]. 
ternational organization and states.The U.S. congress condemning Sudan's general record on human rights and its "policy oflow-intensity ethnic cleansing," declared acts occurring in Sudan to be genocide (Sudan Peace Act, 2002). In contrast, other institutions refrain from using the term genocideand some claim the events in Darfur constitute ethnic cleansing (Richter \& Farley, 2004). The UN Security Council, The E.U. and countries such as France and Germany have concluded evidence does not point to genocide (Destroyed, 2004). Whereas others maintainthat, it constitutes neither genocide nor ethnic cleansing, rather it is an armed conflict (Margaret Neighbor, 2004). The commission of inquiry formed by the UN Security Council argues, "International offences such as crimes against humanity and war crimes that have been committed in Darfur may be no less serious and heinous than genocide" (United Nations Secretary-General, September 2004). When the UN Security Council refers the case to the international criminal court (ICC) prosecutor for accusation through resolution the US was the only state among the veto powers alleging the crime as crime of genocide (Mamdani, 2007). Had it been not for the purpose of political interests the conflict would be characterized based on objective parameters. Commentators such as Mamdani argues that, what has happened against Darfur does not constitute crime of genocide since the intent element is absent, though, the atrocities was widespread like ethnic cleansing accompanied by grave intimidation and violence.

The alleged attack of Serbian against Croatian and Bosnian populations which leads the formation of the ICTY was acknowledged as a pre-planned campaign of ethnic cleansing against non-Serb peoples" (Yacob, 1999). Two years after the UN Security Council adopt the statute of ICTY in the mid1995 the majority of ethnic cleansing was being carrying out by nationalist Serbs (Banac, 1992). The tribunal was entitled to adjudicate grave breach of the Geneva Convention 1949 on violation of the law and custom of war, genocide ${ }^{5}$ and crime against humanity. ${ }^{6}$ In Rwanda, the deliberate nature of the genocide had proven in part by the massive propaganda operation that preceded it and continued for the duration of the violence (Yacob, 1999). The Tutsis was painted as foreign intruders and exploiters who kept the Hutu majority in bondage. (Ibid). Hence, the killings were carried out to establish a homogeneous ethnic power through ethnic cleansing. (Ibid). The mass atrocities in Rwanda were undertaken largely by local militia i.e. Interhamwe in pursuance of establishing homogenous ethnic power through ethnic cleansing. (Ibid). Then the ICTR was established by the UN Security Council primarily to address the crime of genocide. In the Akayesu case, the Tribunal authoritatively determined that genocide against the Tutsi did, in fact, taken place in Rwanda in 1994 (Prosecutor v. Akayesu, 1996). Looking into the history of each conflict one would not fail to acknowledge as the alleged

${ }^{5}$ The list in the statute constituting crime of genocide are exactly similar with what is provided under art 2 of the 1948 genocide convention.

${ }^{6}$ Article 5 of the ICTY Statute defines crimes against humanity as "murder, extermination, enslavement, deportation, imprisonment, torture, rape, persecutions on political, racial and religious grounds and other inhumane acts". 
crime referring as (crime against humanity or genocide) in the tribunals was based on ethnic cleansing.

Even if it is, grave enough labeling a certain atrocities, as ethnic cleansing may not be the best term to describe owing from a number of justifications. For instance, ethnic cleansing does notcall for the international community to take action, in contrast to thecrime of genocide or crime against humanity. International law compels the state to prevent and punish perpetrators of genocide. Nevertheless, characterizing a certain atrocity to genocide requires a careful assessment. The international crime of genocide carries withit a horrifying colloquial connotationeven the Nazi Germany was prosecuted on crime against humanity owing from the strict requirements for a crime of genocide (Schabas, 2006; Trial of German Major War Criminals 38, 2001). Again, to characterize it as crime against humanity it should fulfill the contextual requirement attached with the crime; the attack must be forwarded against civilians in a widespread or systematic manner. ${ }^{7}$ However, no such labeling provided in the crime of ethnic cleansing. Nor is the ICC statute specifically conferring such power to the ICC. Those irrespective of the gravity of the offense committed, prosecuting perpetrators such as the Darfur atrocities depends on word choice. If the international community determines the acts in Darfur are ethnic cleansing, Al-Basher may continue to escape prosecution. The confusion over terms therefore affects the international community's ability to implement applicable international law and to bring justice to millions of people (Manashaw Linnea, 2005).

\section{Requirement of Specific Intent in Genocide}

The contextual element of "specific intent to destroy in whole or in part" to characterize the incident as genocide is unique requirement compared to other core international crimes. Pursuant to article 2 of the Genocide Convention, specific intent refers committing one of the crimes mentioned in the same article to destroy in whole or in part national, religious etc. group. The crime of genocide requires the specific intent to destroy. Accordingly, international tribunals and legal scholars consider displacing an ethnic group to achieve an ethnically homogenous territory is incompatible with genocidal intent (Micol Sirkin, 2009: p. 3). The ICTY in Krstic case interpreting the "intent to destroy" in particular the word destruction in light of customary international law stated, the definition of ${ }^{7}$ The term 'widespread' has been defined in various ways, and generally connotes the 'large-scale nature of the attack and the number of victims'. (see Tadic' ICTY T. Ch. II 7.5.1997 para. 206; Kunarac ICTY T. Ch. II 22.2.2001 para. 428; Nahimana, ICTR A. Ch. 28.11.2007 para. 920; Situation in Darfur (Al Bashir arrest warrant case) ICC PTC-I, 4.3.2009 para. 81). Whereas the requirement of systematic attack has given different definitions in various tribunals the most recent cases seem to be settling on 'the organized nature of the acts of violence and the improbability of their random occurrence. (See, e.g. Nahimana, ICTR A. Ch. 28.11.2007 para. 920; Al Bashir arrest warrant case ICC PTC-I, 4.4.2009 para. 81). The existence of 'high degree of organization, and that features such as patterns, continuous commission, use of resources, planning, and political objectives' are important factors to magnify the attack as systematic. (see an introduction to international criminal law and procedure, second edition, Cambridge, pp. $236 \& 37$ ). However, there is variety of stands towards the existence of policy in the furtherance of systematic attack. 
genocide is limited to those acts seeking either biological or physical destruction of the group. (Ibid). The European Court of Human Rights emphasizing from the ICJ ruling, draws a distinction between ethnic cleansing and genocide in particular stating genocide requires 'deliberately inflicting on the group conditions of life calculated to bring about its physical destruction in whole or in part', carried out with the necessary specific intent (dolus specialis) (Judgment of Jorgic v. Germany, 2007). ${ }^{8}$ While, ethnic cleansing has concerning on displacing and bringing homogeneity. The ICTY trail chamber depicting that the policy of genocide and ethnic cleansing has obvious similarity, (Prosecutor v. Krstic, 2002, par. $576 \& 580$ ) provides that, mere expulsion of a group or part of a group itself does not suffice for genocide. According to the ICTY whenever the forcible removal of an ethnic group constructively causes physical destruction, it may constitute a genocidal act. In the landmark case of Akayesu, ICTR specifically stipulates, a condition of life calculated to bring about a group's physical destruction [in a place] comply the intent requirement. (Prosecutor v. Akayesu, 1998). A replica of this statement has also stipulated by the ICJ providing the act of deportation or displacement with a view to bring homogeneity accompanied by destruction would qualify as crime of genocide (Bosn. \& Herz. v. Serb. \& Mont., 2007). My theme argues the mass destruction of a particular group through grave violence and intimidation such as killing, torture, rape, enforced disappearance, arrest, terrorizing the civilians, abducting women, children etc. with the intention to clear them in a specific placeconstitute crime of genocide. In such case, the intent requirement match's incidentally through the act in the furtherance of the initial purpose. This scenario happens when the act of ethnic cleansing is accompanying through the intent of destruction. For instance, in Krstić, case the ICTY appeal chamber affirming the trial chambers finding and decision states that theforcible transfer of women was using in support of the intent to physical destruction (Prosecutor v. Krstić, 2001 \& 2004). On the other hand, when the material act of ethnic cleansing does not comply with the requirement of genocide it may fallto other crimes (John Quigley, 1999). Ethnic cleansing is widely applied to many different crimes, which taken separately would demandindividual international responsibility as an international crime in thestrict sense (Ibid). For instance, the ICTY, while trying the Tadic case borrowed the term ethnic cleansing from the Security Council report and described the atrocities in the Former Yugoslavia, and tried the defendant for crimes against humanity (Schabas, 2006).

There is nobright-line rule dictating how many people must be harmed to deduce an act as crime of genocide. Nevertheless, the evidence shall show considerable number of the population to that group has targeted to bring about destruction (Prosecutor v. Krstic, 2002, par. 576 \& 580). Although the number of persons died is to be determined by the court on case-by-case basis, ICTY contends "a reasonably significant number, relative to the total of the ${ }^{8}$ The ECHR is based on the ICJ's advisory opinion in Croatia v. Serbia, 2008. 
group as a whole has to be harmed through the perpetration (Prosecutor v. Goran Jelisi, 1999). Forinstance in Rwanda while trying in the crime of genocide the estimated number of death was between 500,000 and one million (Yacob, 1999).

\section{Crime of Ethnic Cleansing and the Principle of Legality}

The principle of legality contained underarticle 15(1) of the ICCPR, article 7(2) of the African charter on human and peoples right, article 7(1) of European convention on human rights, article 9 of the American convention on human rights and article 11(2) of the UDHR, recognizes that there shall be no offense unless in the existence of clearly provided previous laws. This principle further prohibits punishment (including the imposition of greater punishment) unless it is expressly provided as such under national or international laws. In line with this, the criminal code of Ethiopia without sticking the national or international status of a given "law" equally recognizes the principle of legality. ${ }^{9}$ The principle of legality further incorporates the principle of non-retroactivity, specificity and theprohibition of analogy of offenses and punishments. The purpose of the principle is the protection of individuals from prosecution and punishment of an offense to which they did not have been anticipating (ICRC advisory service, 2014). It is based on the idea that individuals shall be given a safe warning to their act, so that they will be obliged totake the risk of their deed. The principle of legality is a fundamental defense for a criminal law prosecution. Its proponent's accepting the expansive interpretation of the principle pledge that the principle of nullum crimen sine lege (NCSL) jurisprudence does not compromise theinternational community fundamental right to prosecute crimes under modern international criminal law proceedings (Beth Van Schaack, 2011). Justifying this itstipulates that, consistent with the formulations of the principle, authoritative interpretations emerging from institutions charged with enforcing human rights protectionand the purposes underlying the NCSL principlebe based on international law. (Ibid).Which means, the principle of legality itself flows from international law norm and practice. (Ibid). The draft history of the UDHR depicting the inclusion of "international law" provision confirms the drafters ${ }^{\text {ee }}$ rejection of the strict requirement of a written statute for prior notice of a crime. (Letter of Lord Dukeston (UK), UN Doc. E/CN.4/21). This stand of the UDHR is also envisaging in the ICCPR. ${ }^{10}$ Commentators argue the approach adhered by the covenant absorbs exception to the principle of legality for crime having international nature (Ferdinandusse, 2006). Although, it is not a reason to derogate from the principle of legality in this perspective, it arguably invites for the lenient application of the principle in the case of international crimes. In ${ }^{9}$ The criminal code of the federal democratic republic of Ethiopia proclamation no. 414/2004, art 2. (The Criminal Code herein after).

${ }^{10}$ International Covenant on Civil and Political Rights (ICCPR), 23 March 1976, UNGA Res, 2200, art 15. 
various tribunals, the approach has reflected in different case developments. For instance, prior to the ICTR's Akayesu judgment, rape and sexualviolence was not crime of genocide under the Rwandan penal law (Opinion of Theodor Meron, 2019). ${ }^{11}$ The defendant argued in trial that the principle of legality provides a fundamental defense, so that prosecution without clearly stipulated previous law would violate the defendant's human right. Nevertheless, the trial emphasizing onimmorality and criminality rejected the defense in the face of malum in se conduct, in particular crimes of mass atrocities and heinous conduct that for whateverreason fells outside of extant positive law (Beth, 2011). In line with this, the European court of human right pledges, where judicial developments are consistent with the essence of an offense and could havebeen reasonably foreseen, the prosecution is not arbitrary or unjust. (Ibid). The court in particular contends whenever the defendant has noticed the fact that his act will impose sanction according to international or domestic laws there is a justification to hold him criminally responsible. (Ibid). Earlier to this, international military tribunal (IMT) recognizes the duty of foreseebility in light of the principle of legality at the Nuremburg trial. According to this trial although the crimes are new which are not ratified by the concerned state they had become recognized by all "civilized nations" as violations of the lawsand customs of war (International military tribunal, 1946). Some scholars have reached a conclusion that since Nuremberg and Tokyo, the international community has assumed that the prosecution of grave international crimes has become common knowledge (Paust, 1997). Mr. Krstić in the ICTY was accusedbased on foreseeing the destructionof the Bosnian Muslim population and tried in the crime of genocide because he must have known that the displacement of the women would contribute to the physical destruction of the Bosnian Muslim population (Prosecutor v. Krstic, 2002). Furthermore, the UN Secretary General noted that "the application of the principle of nullum crimen sine lege does not prevent the tribunal to interpret crime in light of customary law such as international humanitarian law (UN Secretary General Report, 1993). The most important point in the characterizations of ethnic cleansing towards genocide is distinguishing the intent to destroy with the primary aim of the "intent to displace". ICJ recognizing the possibility of incorporating ethnic cleansing underArticle II of the Genocide Convention warns the interpretation to consider ethnic cleansing accompanied by the intent of dislocation and ethnic cleansing accompanied by destruction (ICJ advisory opinion, 2008).

To recap, this paper concludes that ethnic cleansing committed with the requirement of the international genocide law shall be prosecuted based on crime of genocide. Ethnic cleansing lacking this element will fall under other core international crimes in particular crime against humanity as far as it was made accompanying through widespread or systematic attack.

\footnotetext{
${ }^{11}$ Judge at Appeals Chambers of the ICTY and the ICTR; Former President of the ICTY.
} 


\section{The Criminal Code of Ethiopia and Ethnic Cleansing}

Neither the FDRE constitution nor the criminal code employs the word ethnic cleansing. The constitution under the caption crime against humanity provides that criminal liability of persons who commit crimes against humanity, defined by international agreements ratified by Ethiopia and by other laws of Ethiopia, such as genocide, summary executions, forcible disappearances or torture shall not be barred by statute of limitation. ${ }^{12}$ The revised criminal code criminalizes genocide captioning under crime in violation of international law. ${ }^{13}$ Those provisions adhere assimilation approach to crime of genocide and crime against humanity. One may confuse in the wording of the two stipulations in the constitution and thecriminal code. While the former says crime against humanity and only mentioned genocide as other crime without defining it, the later termed genocide ${ }^{14}$ saying nothing about crime against humanity. The 1957 penal code adhering a mixed approach of crime against humanity and crime of genocide explicitly says crime of genocide and crime against humanity in Article 281 though with no substantial difference in the content of the crime except intent requirement. Jean Graven the drafter of this codebelieved that genocide and crimes against humanity overlap each other (Yacob, 1999). In the eyes of this author, both the constitution and the criminal code endorse certain vagueness. The constitution only mentioned the words without certain definition and content. Of course, one may argue the constitution is general and it has paved the way to define based on domestic and international laws (with recognizing all defects in terms of definition and element thereafter). The criminal code seems to incorporate at least based on the element of crime against humanity broadly in time of armed conflict from article 270-273. However, firstly, crime against humanity is not recognizing in time of peace. This is contrary to international law abandoning the nexus between crimes against humanity and armed conflict. ${ }^{15}$ This glaring omission will lead us to the conclusion that, one, if the act has committed with the required intent it will qualify as crime of genocide. Two, a crime committed in the non-existence of armed conflict though widespread or systematic if it lacks the required intent to qualify as crime of genocide it will not be tried based on crime against humanity at least in accordance with criminal

${ }^{12}$ See article 28 of the federal democratic republic of Ethiopia constitution, proclamation no. 1/1995. ${ }^{13}$ See article 269 of the criminal code.

${ }^{14}$ The definition provided according to the criminal code and acts constituting crime of genocide except recognizing genocide based on political grounds substantially similar with the genocide convention.

${ }^{15}$ Today, international law has abandoned the nexus or link between crimes against humanity and armed conflict. The statute of the Nuremberg tribunal of 1945 defined Crimes against humanity focusing on crimes committed during war, the statute of ICTY (art. 5) itself restricted crimes against humanity to those crimes "committed in armed conflict' whether international or internal in character. However, the jurisprudence of the ICTY (the tribunal) and ICTR (statute) later changed this approach abandoning the link between war and crime against humanity. (See Prosecutor v. Tadic" (ICTY) Case No. IT-94-1-AR72, decision on the Defense Motion for Interlocutory Appeal on Jurisdiction, 2 October 1995, Para. 141). Now, it seems well settled that a nexus to armed conflict is not required including under the ICC statute. 
code. Almost a similar problem was encountered the ICTY that, in the Yugoslavian penal law no provision was there dealing about crime against humanity. In such case one may question how would the court handle the interest on the principle of legality and the interest of punishing the perpetrator? The tribunal however, resolved in an interesting stratagem, stating the Yugoslavian law reserves most serious penalty such as crime of genocide which is similar in nature with crime against humanity (Prosecutor v. Erdemovic, 1996). This statement of the court was similar to the stand adopted by the IMT discussed above. The ICTY in particular recognizing crime against humanity is a serious crime imposing severe punishment, considered the importance of article 15 (1) of the ICCPR while providing the principle of legality empowers the court to trial and punishment which is a criminal according to the general principle of law recognized by the community of nation. ${ }^{16}$ The argument towards applying the law governing crime of genocide to crime against humanity was mentioned by the Central High Court in a case between Mengistu Hailemariamand et al., confirming genocide is one kind of crimes against humanity (Special Prosecutor v. Colonel Mengistu Hailemariam et al., October 1995, Para. 106). Therefore, the prosecutor needs to prove that the intent of the perpetrators was to exterminate or destroy in whole or in part, the members of the group to charge based on crime of genocide in other case committed in a widespread or systematic manner would be considered as crime against humanity.

Yet, the criminal code itself lacks inclusivity in terms of incorporating list of acts even in crime of genocide to constitute crime against humanity contrary to accepted international jurisprudence. ${ }^{17}$ To overcome this problem this theme proposes alternatively, first, since the international criminal law jurisprudence after the IMT and Tokyo trial abandon the link or nexus between crime against humanity and armed conflict, attack against civilians under article 270 of the criminal code may be interpreted as equally applicable in time of peace as well. Second, acts such as killing, bodily harm or serious injury to the physical or mental health, compulsory movement etc. provided in the criminal code article 269 can be interpreted broadly to include any conducts bringing the consequence of harm, mental or physical abnormality. In such case if, the act does not fall under the realm of genocide because the perpetrator lacks the required intention they would be prosecuted based on crime against humanity as far as the act is committed systematically or in a widespread manner. Nevertheless, in approaching the crime based on this, one shall distinguish aggravated homicide ${ }^{16}$ Regarding the nature, type and extent of punishment, the ICTY and ICTR statute and later their respective tribunals adhered some reference to the general criminal practice of the state concerned while the ICC statute completely delete a provision initially proposed by international law commission of the UN General Assembly dealing with reference to national law owing from equality issue among perpetrators.

${ }^{17}$ Murder, extermination, enslavement, deportation, torture, rape, enforced disappearance, enforced prostitution or any inhuman acts committed against any civilian population, persecutions on political, racial or religious grounds in execution of or in connection with any crime are some commonly provided crimes against humanity as stipulated in the statute of ICC, ICTY and ICTR. 
(usually committed against individuals) and crime against humanity. Among the objections' raised by the defense lawyer in Mengistu and et'al case against the charges and dissenting judge opinion was that, it did not distinguish between the crimes of genocide and crimes against humanity as well as aggravated homicide and willful injury (Firew, 2007). In a majority judgment of two to one, the court convicted the accused through genocide while the dissenting judge found them guilty of aggravated homicide (Yalemfiker G. Moges. March 2010). ${ }^{18}$ The third possibility is following the FDRE constitution article 28 so that crime against humanity can be defined based on international laws. Of course, it is not only through the constitution, the criminal code itself caption it as crime in violation of international law strengthening this term of argument. This is consistent with Ethiopia's international obligation to criminalize acts condemned by international conventions or customary international criminal law as fundamental crimes $^{19}$. An international core crime against humanity as defined somewhere above, have the status of Jus cogens constituting obligatio erga omnes (Malcolm Shaw, 2003: pp 68-84). This obligation is not subject to derogation. In such case, although Ethiopia is not a signatory of the ICC statute we can refer based on the idea of cross-fertilization as well as the developed jurisprudence of ICTR and ICTY. The other layout would be widening the scope of crime against humanity in the constitution or genocide in the criminal code via explicit recognition of crime against humanity (in peacetime) and ethnic cleansing in the long run through amendment.

\section{Conclusion}

To sum up, no doubt, perpetrator of ethnic cleansing may go unpunished ${ }^{20}$ nor is applying ordinary provision of the criminal code sufficiently address it, criminalizing ethnic cleansing must be studied in light of international criminal law and jurisprudence. Based on this if ethnic cleansing has been committed with intent to physical destruction of a specific group in a place accompanied by the underlying offense of genocide constitutes as crime of genocide. In the absence of such particular intent of physical destructionbut committed in a widespread ${ }^{18}$ The dissenting opinion by Judge Nuru Seid found however that, the accused should have been convicted of homicide and causing willful bodily injury, not genocide. He came to this conclusion in light of the argument of the accused that their actions at the time were lawful and the measures taken against political groups and their members did not amount to genocide in international law." This positivist line of argument nevertheless may be disproof by the fact that the Nazis bounds by the law when they committed the atrocities with which they were subsequently charged. (See Yalem fiker Girma Moges, collective criminal responsibility of the Derg members in the case of special prosecutor v. colonel Mengistu Hailemariam et al., a thesis for LLM at Addis Ababa University, Ethiopia, law faculty, postgraduate studies, March 2010).

${ }^{19}$ Although there are some arguments regarding the application of custom by Ethiopian courts in particular stating, the constitution doesn't explicitly allow interpretation unlike treaties, proclamation No. 321/2003 (an amendment to the federal courts proclamation No. 25/1996), expressly provides the need to adore customary international law in interpreting domestic laws.

${ }^{20}$ This argument was adhered by the IMT, stating the principle of legality does not prohibit punishing, in the circumstance that the perpetrator must know he is doing wrong, in such case it would be unjust to let him unpunished than punishing. 
or systematic manner, it must be considered as crime against humanity.

\section{Conflicts of Interest}

The author declares no conflicts of interest regarding the publication of this paper.

\section{References}

(2007). Case Concerning the Application of Convention on Prevention and Punishment of the Crime of Genocide (Bosn. \& Herz. v. Serb. \&Mont.). I.C.J. 1, 73.221.

Banac, I. (1992). The Fearful Asymmetry of War: The Causes and Consequences of Yugoslavia's Demise. Daedalus, 121, 141-174.

Beth, V. S. (2011). The Principle of Legality in International Criminal Law. Santa Clara Law Digital Common.

Convention on the Prevention and Punishment of the Crime of Genocide, Dec. 9, 1948, Res. 102.

Croatia v. Serbia (2008). ICJ's Advisory Opinion.

Destroyed, D. (2004). Ethnic Cleansing by Government and Militia Forces in Established Principles in Light of Contemporary Interpretations, Seattle University Law.

Ferdinandusse, W. (2006). Direct Application of International Criminal Law in National Courts. Final Report of the United Nations Commission of Experts Established Pursuant to Security.

Firew, T. (2007). The Trial of Mengistu and Other Derg Members for Genocide, Torture and General Principle of International Criminal Law. ICRC Advisory Service for International Humanitarian Genocide. New England Law Review, 35, 287-296.

IMT (1946). Judgment in the Trial of German Major War Criminals 467.

International Military Tribunal (1946). Judgment in the Trial of German Major War Criminals 467.

Judgment of Jorgic v. Germany (2007). The European Court of Human Rights Court. Motion for Interlocutory Appeal on Jurisdiction.

Malcolm, S. (2003). International Law (5th ed.). Cambridge: Cambridge University Press.

Mamdani, M. (2007). The Politics of Naming: Genocide, Civil War, Insurgency. London Review of Books, 29, 5-8.

Manashaw, L. (2005). Genocide and Ethnic Cleansing: Why the Distinction? A Discussion in the Context of Atrocities Occurring in Sudan.

Margaret, N. (2004). Ethnic Cleansing Shame of Sudan, the Scotsman. Members in the Case of Special Prosecutor v. Colonel Mengistu Hailemariam et al. A.

Micol, S. (2009). Expanding the Crime of Genocide to Include Ethnic Cleansing: A Return to Nations.

Moges, Y. G. (2010). Collective Criminal Responsibility of the Derg Yugoslavia's Demise, Daedalus.

Paust, J. J. (1997). It's No Defense: Nullum Crimen, International Crime and the Gingerbread Problems of International Codification, the Atrocities in Cambodian and Kosovo.

Presbyterian Church of Sudan v. Talisman Energy (2003). Inc, 244 F. Supp. 2d 289, 296 n. 2.

Prosecutor v. Akayesu, ICTR (1996). A Judgment ICTR-96-4-T, T Ch I. 
Prosecutor v. Erdemovic (1996). ICTY, No. IT-96-22-T, Sentencing Judgment.

Prosecutor v. Goran Jelisi (1999). ICTY, No. IT-95-10-T.

Prosecutor v. Krstić (2001). Case No. IT-98-33-T, Judgment, 594.

Prosecutor v. Krstic (2002). No. IT-98-33-T, Judgment.

Prosecutor v. Krstić (2004). Case No. IT-98-33-A, Judgment.

Report of the Secretary-General (1993). Pursuant to Paragraph 2 of Security Council Resolution 808, 34, U.N. Doc. S/25704.

Richter, P., \& Farley, M. (2004). U.S. Declares Darfur Crisis Is Genocide, L.A. TIMES.

Schabas, W. (2001). Symposium: Universal Jurisdiction: Myths, Realities, and Prospects.

Schabas, W. (2006). Preventing Genocide and Mass Killing: The Challenge for the United Secretary-General, Pursuant to Security Council Resolution. (2004). 1564. Security Council Resolution 808, 34, U.N. Doc. S/25704.

Special Prosecutor v. Colonel Mengistu Hailemariam et al. (1995). Central High Court of the Transitional Government, Rulings on Preliminary Objections, No. 1/878.

Sudan Peace Act of 2002 (2002). Pub. L. No. 107-245 S 2 (10), 116 Stat 1504. Summary Executions in Ethiopia. http://hdl.handle.net/10536/DRO/DU:30068884

The Federal Democratic Republic of Ethiopia Constitution Proclamation Number 1/1995.

The Secretary-General (1993). Report of the Secretary-General Pursuant to Paragraph 2 of Thesis for LLM at Addis Ababa University, Ethiopia, Law Faculty, Postgraduate Studies, $U K$.

Trial of German Major War Criminals 38 (2001). Judgment of the International Military Tribunal for the Trial of German Major War Criminals, Nuremberg, Sept. 30 \& Oct. 1.

Yacob, H.-M. (1999). The Quest for Justice and Reconciliation: The International Criminal Tribunal for Rwanda and the Ethiopian High Court. Hastings International and Comparative Law Review, 22, 668-699. 